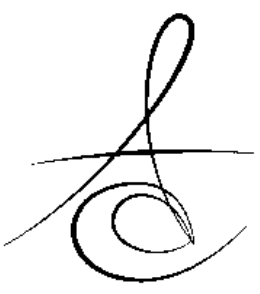

\title{
RETROSPECTIVE EVALUATION OF THE RELATIONSHIP BETWEEN VOLUMES OF PARANASAL SINUSES, PRESENCE OF RHINOSINUSITIS AND NASAL SEPTUM DEVIATIONS ON CBCT IMAGES
}

\section{PARANAZAL SİNÜSLERİN HACİMLERİ, RİNOSİNÜZİT VARLIĞI VE NASAL SEPTUM DEVİASYONLARI ARASINDAKİ İLIŞKİNİN KONİK IŞINLI BİLGİSAYARLI TOMOGRAFİ GÖRÜNTÜLERİNDE RETROSPEKTİF OLARAK DEĞERLENDİRİLMESİ}

\author{
Uzm. Dt. Burcu KİRŞAN BÜYÜKKOÇAK*
}

Prof. Dr. Candan Semra PAKSOY**

Makale Kodu/Article code: 3871

Makale Gönderilme tarihi: 06.11.2018

Kabul Tarihi: 16.04 .2019

\section{ABSTRACT}

Aim: The aim of this study is to evaluate the relationship between nasal septum deviations, volumes of paranasal sinuses and Lund-Mackay scores related with the presence of rhinosinusitis in conebeam computed tomography images, which is currently been used in dental radiology.

Material and method: CBCT images of 130 patients aged between 18 and 79 years with paranasal sinus area in our study were evaluated retrospectively. The correlation between the Lund-Mackay scores related with the presence of rhinosinusitis, the paranasal sinus volumes and nasal septum deviations which is an anatomic variation commonly seen in the community were examined.

Results: Of the 130 patients who constituted the study group, 103 (79.2\%) had nasal septum deviations, $53(51.5 \%)$ to the right and $50(48.5 \%)$ to the left. The total Lund-Mackay scores of individuals with nasal septum deviation were significantly higher than those without nasal septum deviation $(p \leq 0.05)$. According to the results of our study, right and left maxillary, frontal, sphenoid and ethmoid sinus volumes were $13.6 \mathrm{~cm}^{3}, 14.5 \mathrm{~cm}^{3}, 6.2 \mathrm{~cm}^{3}, 9.7 \mathrm{~cm}^{3}$, $8.7 \mathrm{~cm}^{3}$ respectively.

Conclusion: As an alternative of Computed Tomography, which is accepted as gold standard to evaluate the relationship between nasal septum deviation and paranasal sinus volume with the presence of rhinosinusitis, Cone Beam Computerized Tomography, which allows a 3-dimensional radiological examination with a lower dose of radiation, may be used instead.

Keywords: CBCT, Nasal septum deviation, Volume of paranasal sinuses, Lund-Mackay Score, Chronic rhinosinusitis.

\section{öz}

Amaç: Çalışmanın amacl, günümüzde diş hekimliği radyolojisinde kullanılan Konik Işınlı Bilgisayarlı Tomografi görüntülerinde nazal septum deviasyonları, paranazal sinüslerin hacimleri ve Lund-Mackay skorları ile buna bağlı rinosinüzit varlığı arasındaki ilişkiyi değerlendirmektir.

Gereç ve Yöntem: Çalışmamızda paranazal sinüs bölgesinin görüntü alanı içinde bulunduğu, yaşları 18 ile 79 arasında değişen 130 hastaya ait KIBT görüntüsü retrospektif olarak değerlendirilmiştir. Toplumda yaygın olarak görülen anatomik varyasyon olan nazal septum deviasyonu, paranazal sinus hacimleri ve Lund-Mackay skorları ile buna bağlı rinosinüzit varlığı arasındaki ilişki incelenmiştir.

Bulgular: Çalışma grubunu oluşturan 130 hastanın, 53 'ü $(\% 51,5)$ sağa, 50 'si $(48,5)$ sola olmak üzere 103 'ünde $(\% 79,2)$ nazal septum deviasyonu bulunmuştur. Nazal septum deviasyonu olan bireylerin toplam Lund-Mackay skorları, deviasyonu olmayanlara göre anlamlı düzeyde yüksek bulunmuştur $(p \leq 0.05)$. Çalışmamızın sonuçlarına göre, sağ ve sol maksiller, frontal, sfenoid ve etmoid sinus hacimleri sırasıyla 13.6 $\mathrm{cm}^{3}, 14,5 \mathrm{~cm}^{3}, 6,2 \mathrm{~cm}^{3}, 9,7 \mathrm{~cm}^{3}, 8,7 \mathrm{~cm}^{3}$ olarak ölçülmüştür.

Sonuç: Nazal septum deviasyonu ve paranazal sinüs hacminin rinosinüzit varlığı ile arasındaki ilişkinin değerlendirilmesinde altın standart olarak kabul edilen Bilgisayarlı Tomografiye alternatif olarak; daha düşük radyasyon dozuyla 3 boyutlu incelemeye olanak sağlayan Konik Işınlı Bilgisayarlı Tomografi tercih edilebilir.

Anahtar Kelimeler: KIBT, Nazal septum deviasyonu, Paranazal sinüslerin hacmi, Lund-Mackay Skorlaması, Kronik rinosinüzit.

*T.C. Sağlık Bakanlığı, Mamak Ağız ve Diş Sağlığı Merkezi, Ankara

** Ankara Üniversitesi, Diş Hekimliği Fakültesi, Ağız, Diş ve Çene Radyolojisi A.D., Ankara 


\section{INTRODUCTION}

Paranasal sinuses are structures that form anatomical and functional unit with nasal fossa consisting of four pairs of air-filled cavities located in the bone surrounding the nasal cavity and are closely related to the nasal cavity, upper airway and jaw development due to their location. ${ }^{1}$ Anatomic variations are frequent in the sinonasal region, so it is very important to assess the paranasal region in the diagnosis and treatment of paranasal sinus diseases. ${ }^{2}$

$3 \mathrm{D}$ imaging modalities have become an indispensable diagnostic tool in the evaluation and treatment of anatomy, pathology and surgical complications. ${ }^{3} \mathrm{As}$ an alternative to Computed Tomography (CT) which is accepted as gold standard in evaluation of variations of sinonasal region anatomy and is preferred before endoscopic sinus surgery, Cone Beam Computerized Tomography (CBCT) which allows a 3-dimensional radiological examination with a lower dose of radiation may be used instead. ${ }^{4}$

The aim of the present study is to evaluate the correlation between nasal septum deviations, presence of rhinosinusitis and paranasal sinus volumes on CBCT images, which is currently been used in dentomaxillofacial radiology.

\section{MATERIALS AND METHODS}

Approval from the Ethical Committee of the Faculty of Dentistry, Ankara University (No. $36290600 / 01$ ) was obtained for the study, then the images of 2150 patients who were referred to Ankara University, Faculty of Dentistry and had a CBCT image for different purposes were retrospectively screened. The study included images of individuals who were found in the visual field of paranasal sinuses, who were not traumatized or accident in the head and neck region, who did not have any tumor formation in the areas to be examined and who did not undergo surgical operations. 130 images that were obtained from a total of 71 male (54.6\%) and 59 females (45.4\%) patients aged between 18 and 79 (mean age 37.72 ), and who provided these inclusion criteria were used.

Three-dimensional data were acquired using a ProMax 3-D Max CBCT device (Planmeca, Helsinki, Finland), using low artifact reduction mode operating at $96 \mathrm{kVp}, 9-10 \mathrm{~mA}$, and $230 \times 170-230 \times 270 \mathrm{~mm}$ field of view at $0.4 \mathrm{~mm}^{3}$ voxel size (nominal cubic $\mathrm{mm}$ resolution $\left[\mathrm{mm}^{3}\right]$ ). The exposure time ranged 9-10 seconds. Reconstructed projection images were processed with reformatting software (Romexis software, version 3.2.0.R, Planmeca, Helsinki, Finland). Multiplanar reformatted images were viewed on a 15.4" Toshiba laptop (Neuss, Germany) at a $1366 \times 768$ screen resolution.

\section{Determination of Nasal Septum Deviation}

Coronal images are the preferred initial procedure in paranasal CT imaging. Coronal images exhibit ostiomeatal complex and other anatomical structures that play an important role in paranasal diseases. ${ }^{5}$ As described previously ${ }^{6}$, coronal sections were examined to determine whether the nasal septum diverted in any direction while determining nasal septum deviations. The deviation angle was accepted as the angle between the linear line drawn from the maxillary spine to the crista galli and the linear line drawn from the crista galli to the most deviated part of the nasal septum. The direction of deviation was described by the convexity of the septal curvature. The determination of the nasal septum deviation on the coronal CBCT image is shown in Figure1.

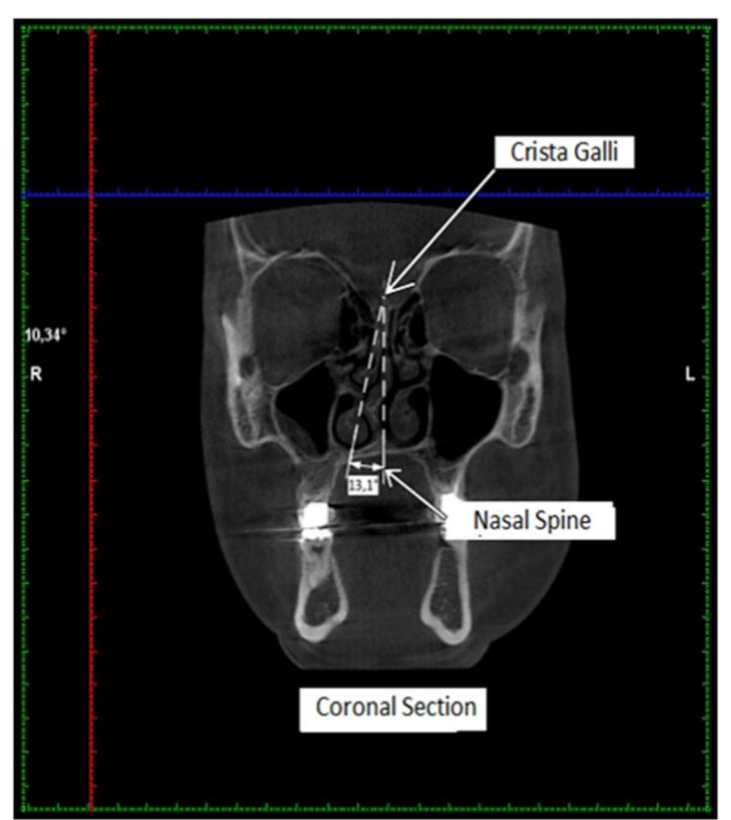

Figure 1. Nasal septum deviation on the coronal CBCT image

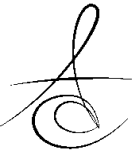




\section{Application of Lund-Mackay Classification to Determine Sinus Pathologies}

Lund-Mackay classification system was used in the evaluation of sinus pathologies. Each paranasal sinus group was examined separately on the left and right sides according to Lund-Mackay scoring system. The sinus groups which included maxillary, frontal, sphenoidal, anterior ethmoidal and posterior ethmoidal sinuses were evaluated as no abnormality $(0)$, partial opacification (1), and total opacification (2). Ostiomeatal complex was also evaluated and scored as 0 (not obstructed) or 2 (obstructed) according to Lund-Mackay scoring system. Thus, scores between 0 to/and 24 have been obtained. The sinus scorings are shown in Figure 2.

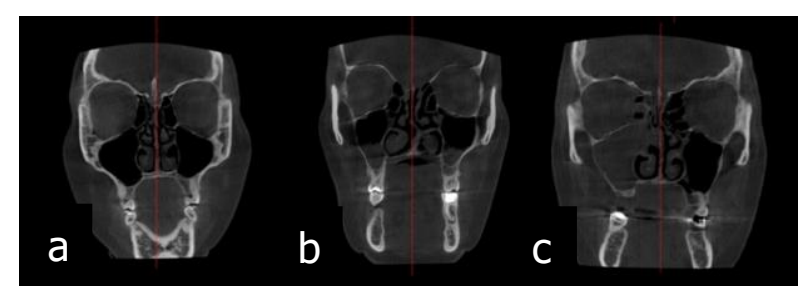

Figure 2. Right maxillary sinus scores $0,1,2$ respectively according to Lund-Mackay classification. Score 0 was evaluated as no abnormality (a), score 1 was evaluated as partial opacification (b), and score 2 was evaluated as total opacification (c).

\section{Measurement of Paranasal Sinus Volumes}

Volumetric measurements of reconstructed $\mathrm{CBCT}$ images were performed by using the software program 3D DOCTOR (Able Software Corp, Lexington, MA, USA) as Digital Imaging and Communications in Medicine (DICOM) files format. The borders of the maxillary, frontal, ethmoid and sphenoid sinus cavities were drawn in the axial slices. Cavity boundaries were determined automatically in the user defined region shown with blue line for maxillary sinus in Figure 3. These $2 \mathrm{D}$ drawings were automatically merged by the program. The volumes $\left(\mathrm{mm}^{3}\right)$ of paranasal sinuses were automatically calculated by the software. Figure 3 shows reconstructed final maxillary sinus image.

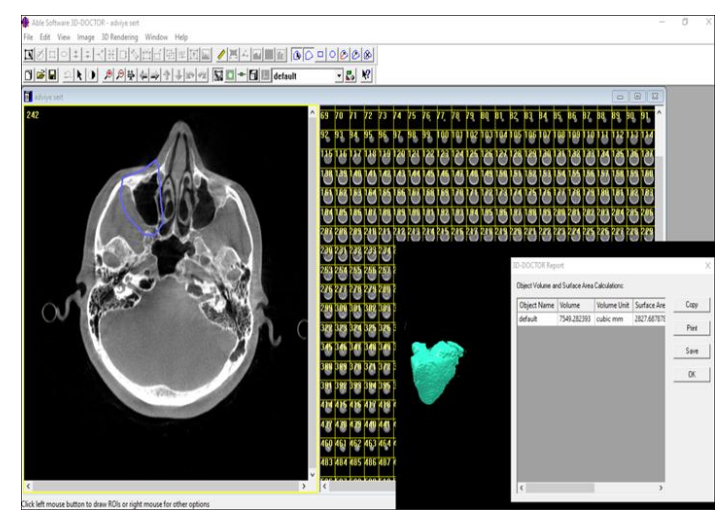

Figure 3. Creation of 3D models of right maxillary sinus

One week after the first examination, intraobserver repeatability was performed by re-evaluation of the 40 images, randomly selected patients from the study group.

T-test was used to compare the presence of deviations, sides and volume measurements according to gender. Pearson correlation coefficient was used to investigate the relationship between age and volume. Intraclass Correlation Coefficient and Kappa tests were used for intra-observer compliance. Significance level was set at $\mathrm{P}<0.05$.

\section{RESULTS}

The descriptive statistics for nasal septum deviation, paranasal sinus volumes and Lund-Mackay scores of all individuals are shown in Table 1.

Table 1. The descriptive statistics for nasal septum deviation, paranasal sinus volumes and Lund-Mackay scores of all individuals

\begin{tabular}{|c|c|c|}
\hline & $\begin{array}{l}\text { Mean } \pm \text { Standard } \\
\text { deviation }\end{array}$ & Median (min-max) \\
\hline Deviation angle $\left({ }^{\circ}\right)$ & $7.27 \pm 2.59$ & $7(2.73-16)$ \\
\hline $\begin{array}{l}\text { Right maxillary sinus } \\
\text { volume }\left(\mathrm{mm}^{3}\right)\end{array}$ & $13617 \pm 6329$ & $13085(0-28369)$ \\
\hline $\begin{array}{l}\text { Left maxillary sinus volume } \\
\left(\mathrm{mm}^{3}\right)\end{array}$ & $14532 \pm 6512$ & $15015(0-31241)$ \\
\hline Frontal sinus volume $\left(\mathrm{mm}^{3}\right)$ & $6247 \pm 1912$ & $6187(1372-14164)$ \\
\hline $\begin{array}{lll}\text { Ethmoid } & \text { sinus } & \text { volume } \\
\left(\mathrm{mm}^{3}\right) & & \end{array}$ & $8691 \pm 3332$ & $8594(1052-17147)$ \\
\hline $\begin{array}{l}\begin{array}{l}\text { Sphenoid } \\
\left(\mathrm{mm}^{3}\right)\end{array} \\
\text { sinus volume }\end{array}$ & $9691 \pm 4651$ & $9151(0-40382)$ \\
\hline Total Lund-Mackay score & $3.85 \pm 3.47$ & $3(0-16)$ \\
\hline
\end{tabular}

Nasal septum deviations were found in 103 of the 130 patients $(79.2 \%)$ who constituted the study group. Fifty three of these deviations were determined 
as a deviation to the right $(51.5 \%), 50$ to the left (48.5\%). Among the patients, $59.2 \%$ of the individuals with deviations were male and there was a statistically significant difference in the distribution of nasal septum deviations by gender $(p<0.05)$. The angle and direction of deviation by gender did not differ statistically ( $p>0.05)$.

The sinus volume measurements were compared according to the direction of septum deviations (Table 2). The average right maxillary sinus volume was found to be greater than average left maxillary sinus volume in patients with left-sided deviation $(p \leq 0.05)$. Also, average left maxillary sinus volume was found to be greater in patients with rightsided deviation but this difference was not statistically significant. There was no significant differences between frontal, ethmoid and sphenoid sinus volumes according to deviation, direction was not statistically significant $(p>0.05)$. Although all paranasal sinus volumes were larger in men than in women, this difference was only significant in frontal sinus volumes.

Table 2. Sinus volume measurements in individuals with and without nasal septum deviation

\begin{tabular}{|l|l|l|l|}
\hline $\begin{array}{c}\text { Paranasal sinus } \\
\text { volumes } \\
\left(\mathrm{mm}^{3}\right)\end{array}$ & $\begin{array}{c}\text { With deviation } \\
(\mathrm{n}=103) \\
\text { Mean } \pm \text { Standard } \\
\text { deviation }\end{array}$ & $\begin{array}{c}\text { Without deviation } \\
(\mathrm{n}=27) \\
\text { Mean } \pm \text { Standard } \\
\text { deviation }\end{array}$ & $\mathrm{p}$ \\
\hline $\begin{array}{l}\text { Right maxillary } \\
\text { sinus }\end{array}$ & $13209 \pm 6564$ & $15170 \pm 5150$ & 0.10 \\
\hline $\begin{array}{l}\text { Left maxillary } \\
\text { sinus }\end{array}$ & $14473 \pm 6611$ & $14757 \pm 6235$ & 0.84 \\
\hline Frontal sinus & $6380 \pm 1817$ & $5742 \pm 2201$ & 0.12 \\
\hline Ethmoid sinus & $8954 \pm 3381$ & $7690 \pm 2990$ & 0.08 \\
\hline Sphenoid sinus & $9739 \pm 4816$ & $9510 \pm 4034$ & 0.82 \\
\hline
\end{tabular}

Lund-Mackay scores of patients with nasal septum deviations were found to be significantly higher than those without deviations. Mean total score of the deviations was $4.25 \pm 3.32$ and mean total score of the non-deviations was $2.33 \pm 3.67$. There were no statistically significant differences between the two groups in terms of total Lund-Mackay score parameters related to deviations and direction ( $p>0.05)$.
It is well known that risk of sinus disease is high in the individuals with Lund-Mackay score 6 or higher. All patients' total Lund-Mackay scores were determined in our study. The total Lund-Mackay scores of individuals were divided into two groups as $<6$ and $\geq 6$, and a statistically significant difference was found between the two groups (Table 3 ). The total paranasal sinus volumes of the patients with Lund-Mackay score 6 and above were found to be small compared to the others $(p<0.001)$.

Table 3. Comparison of the total paranasal sinus volumes of the patients with total Lund-Mackay score $\geq 6$ and $<6$

\begin{tabular}{|r|r|r|l|}
\hline $\begin{array}{r}\text { Total Lund- } \\
\text { Mackay } \\
\text { score }\end{array}$ & $\begin{array}{l}\text { Number of } \\
\text { patients (n) }\end{array}$ & $\begin{array}{l}\text { Mean total paranasal } \\
\text { sinus volumes } \pm \\
\text { Standard deviation } \\
\left(\mathrm{mm}^{3}\right)\end{array}$ & $\mathrm{p}$ \\
\hline$<6$ & 95 & $56444 \pm 14488$ & \multirow{2}{*}{$<0.001$} \\
\hline$\geq 6$ & 35 & $42837 \pm 11154$ & \\
\hline
\end{tabular}

Intra-observer reliability was assessed by using Intraclass Correlation Coefficient and Kappa tests. ICC was found as perfect in all measured parameters $(p \leq 0.000)$. Also, according to kappa values, intraobserver reliability was found as perfect in all measured parameters (kappa>0.918).

\section{DISCUSSION}

Septum deviation is one of the common anatomical variations of sinonasal region. The incidence of nasal septal deviation was $14.1-96.9 \%$ in the literature depending on different criteria, such as the degree of deviation and the morphological characteristics of the septum. ${ }^{7,8}$ In the present study, of the 130 patients who constituted the study group, 103 (79.2\%) had nasal septum deviations, 53 (51.5\%) to the right and $50(48.5 \%)$ to the left.

Smith et al. found the rate of septum deviation higher in women $(56.3 \%)$ than in men $(43.6 \%)$ in their study. ${ }^{9}$ In the present study, the prevalence of septal deviation was found greater in men (59.2\%) than in women (40.8\%). Also, the angle of nasal septum deviation was $7.56 \pm 2.60$ in men and $6.86 \pm 2.57$ in women. In another study ${ }^{10}$, examiners found the angle of the nasal septum deviation $13.88^{\circ}$ (4.9-31.2) in males and $14.18^{\circ}(5.1-34.1)$ in females

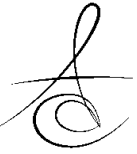


in which only individuals with nasal septum deviation were examined. As in this study, correlation between age, gender and deviation couldn't be found. As it is concluded in present study, in another study ${ }^{11}$, angle of nasal septum deviation was found to be relatively close to each other on the left and right sides.

Determination of paranasal sinus size and volume is the first step in the study of the effects of paranasal sinuses on facial morphology. Therefore, one of the parameters evaluated in this study is the volume of paranasal sinuses.

Emirzeoglu et al. evaluated the volumes of paranasal sinuses on individuals who did not have a sinology-related pathology on CT images of 77 patients. ${ }^{12}$ The volumes of the bilateral maxillary, frontal, sphenoid and ethmoid sinuses were $35.9 \mathrm{~cm}^{3}$, $11.6 \mathrm{~cm}^{3}, 13.6 \mathrm{~cm}^{3}, 11.8 \mathrm{~cm}^{3}$, respectively. Any significant difference in sinus volumes between right and left sides couldn't be found; but it was reported that all sinus volumes except the sphenoid sinus were greater in females in males.

In this study, paranasal sinus volume assessment wasn't evaluated by choosing individuals with or without pathology related to the sinuses; evaluation was performed in the field of the paranasal sinus area on all individuals whose CBCT images were obtained for different purposes. Right and left maxillary, frontal, sphenoid and ethmoid sinus volumes were found $14.3 \mathrm{~cm}^{3}, 15.5 \mathrm{~cm}^{3}, 6.7 \mathrm{~cm}^{3}$, $10.02 \mathrm{~cm}^{3}, 9.03 \mathrm{~cm}^{3}$ respectively in males; $12.7 \mathrm{~cm}^{3}$, $13.3 \mathrm{~cm}^{3}, 5.6 \mathrm{~cm}^{3}, 9.2 \mathrm{~cm}^{3}$ and $8.2 \mathrm{~cm}^{3}$ respectively in females in the present study. Although the mean maxillary, frontal, ethmoid and sphenoid sinus volumes were higher in males than in females, this difference was statistically significant only frontal sinuses. This magnitude difference between both genders is due to sexual dimorphism.

Kennedy et al. suggested that anatomical variations such as nasal septum deviations lead to potential susceptibility to sinusitis. ${ }^{13}$ Computerized tomography of the paranasal sinuses has become the most reliable imaging method to confirm the diagnosis of chronic rhinosinusitis and to plan surgical intervention, although it is not necessary for the clinical diagnosis of many rhinosinusitis. ${ }^{14}$ The LundMackay system, a radiological staging system of chronic sinusitis, was found to be simple and reliable. ${ }^{15,16}$
In the study of Ashraf and Bhattacharyya ${ }^{17}$, it was emphasized that in the majority of the general population, abnormal scores ( 1 and 2 points) counted from the radiological findings of sinusitis according to Lund-Mackay score. If the Lund score is 6 or greater at the end of the CT scan, patients have a higher likelihood of sinus disease.

In the present study, the percentage of nonnormal sinus scores (individuals with scores of 1 and 2) for the right and left sides were found to be respectively $29.2 \%$ and $32.3 \%$ for the anterior ethmoid sinuses, $19.2 \%$ and $21.5 \%$ for posterior ethmoid sinuses, $52.3 \%$ and $60.8 \%$ for maxillary sinuses, $11.5 \%$ and $11.5 \%$ for sphenoid sinuses, $9.3 \%$ and $11 \%$ for frontal sinuses. Ostiomeatal complex blockage rates were detected as $25.4 \%$ for the right side and $33.8 \%$ for the left side. A correlation was found between deviation presence and Lund-Mackay scores according to the results of this study. The mean Lund-Mackay score of patients with deviation was 4.25 and the mean Lund-Mackay score of patients without deviation was 2.33. The Lund-Mackay scores of individuals with nasal septum deviation were significantly higher than of those without nasal septum deviation $(p<0.001)$.

Woo et al. evaluated the efficacy of imaging by performing CBCT before endoscopic sinus surgery in 50 patients. ${ }^{18}$ Endoscopic findings of sinusitis were compared by performing Lund-Mackay scoring on a CBCT scan and significant correlation between them was observed.

Varshosaz et al. conducted a study comparing the efficacy of conventional CT scan and CBCT in the evaluation of paranasal sinuses. ${ }^{19}$ No significant difference between findings detected in both imaging modalities was found. They recommend that CBCT can be used instead of conventional CT scans before surgery when lower radiation dosing is considered.

\section{CONCLUSION}

Results of the present study according to measurements by CBCT images show that presence of nasal septum deviations and decrease in volume of paranasal sinuses are related with increased LundMackay scores which are related with presence of rhinosinusitis. As an alternative of Computed Tomography, which is accepted as gold standard in

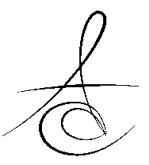


evaluation of variations of sinonasal region anatomy and is preferred before endoscopic sinus surgery, Cone Beam Computerized Tomography, which allows a 3-dimensional radiological examination with a lower dose of radiation, may be used instead.

B. Kirşan Büyükkoçak: $O R C I D I D$ : 0000-0001-5354-1554 Candan Semra Paksoy: ORCID ID: 0000-0002-6961-5172

\section{REFERENCES}

1. Warwick R, Williams PL. Gray's anatomy. 35thEd, Philadelphia: W.B. Saunders; 1973.

2. Sanchez Fernandez JM, Anta Escuredo JA, Sanchez Del Rey A, Santaolalla Montoya F. Morphometric study of the paranasal sinuses in normal and pathological conditions. Acta Otolaryngologica 2000; 120:273-8.

3. Younis R.T, Anand V.K, Davidson B. The role of computed tomography and magnetic resonance imaging in patients with sinusitis with complications. Laryngoscope 2002; 112:224-9.

4. Guldner C, Ningo A, Voigt J, Diogo I, Heinrichs J, Weber $R$, Wilhelm T, Fibeich M. Potential of dosage reduction in cone-beam-computed tomography (CBCT) for radiological diagnostics of the paranasal sinuses. Eur Arch Otorhinolaryngol 2013; 270:1307-5.

5. Çakur B, Sümbüllü MA, Yılmaz AB. Relationship among hypertrophy of inferior turbinate, deviation of nasal septum and antral retention cyst. J Dent Fac Atatürk Uni 2011; 21:5-9.

6. Bhandary S K, Kamath P S. Study of relationship of concha bullosa to nasal septal deviation and sinusitis. Indian J Otolaryngol Head Neck Surg 2009; 61:227-9.

7. Dutra LD, Marchiori E. Tomografia computadorizada helicoidal dos seios paranasais na criança: avaliação das sinusopatias inflamatórias. Radiol Bras 2002; 35:161-9.

8. Calhoun K, Waggenspack G. CT evaluation of the paranasal sinuses in symptomatic and asymptomatic populations. Otolaryngol Head Neck Surg 1991; 104:480-3.

9. Smith KD, Edwards PC, Saini TS, Norton NS. The prevalence of concha bullosa and nasal septal deviation and their relationship to maxillary sinusitis by volumetric tomography. Int J Dent 2010; 2010:1-5.
10. Şerifoglu I, Oz II, Damar M, Buyukuysal MC, Tosun A, Tokgoz O. Relationship between the degree and direction of nasal septum deviation and nasal bone morphology. Head Face Med 2017; 13:1-6.

11. Saylisoy S, Acar M, San T, Karabag A, Bayar Muluk $\mathrm{N}$, Cingi $\mathrm{C}$. Is there a relationship between cribriform plate dimensions and septal deviation angle? Eur Arch Otorhinolaryngol 2014; 271:1067-71.

12. Emirzeoglu M, Sahin B, Bilgic S, Celebi M, Uzun A. Volumetric evaluation of the paranasal sinuses in normal subjects using computer tomography images: a stereological study. Auris Nasus Larynx 2007; 34:191-5.

13. Kennedy DW. Diagnosis and treatment of recurrent sinusitis, JAMA 2000; 284:1240.

14. Zinreich J. Rhinosinusitis: radiologic diagnosis. Otolaryngol Head Neck Surg. 1997; 117:27-34.

15. Lund V J, Kennedy D W. Staging for rhinosinusitis. Otolaryngol Head Neck Surg 1997; 117:35-40.

16. Metson R, Gliklich R, Stankiewicz JA. Comparison of sinus computed tomography staging systems. Otolaryngol Head Neck Surg. 1997; 117:372-379.

17. Ashraf N, Bhattacharyya N. Determination of the "incidental" Lund score for the staging of chronic rhinosinusitis. Otolaryngol Head Neck Surg 2001; 125:483-6.

18. Woo WK, Shin WC, Jung DK, Lee YB, Lee SD. The usefulness of cone beam computed tomography in endoscopic sinus surgery. J Rhinol 2012; 19:45-9.

19. Varshosaz M, Sharifi S. Cone beam volumetric tomography versus conventional computed tomography in evaluation of paranasal sinuses. Tehran Univ Med J 2010; 68:406-11.

\author{
Yazışma Adresi \\ Uzman Dt. Burcu Kirşan BÜYÜKKOÇAK \\ Mobil: 05368474342 \\ Email: burcu.kirsan7@gmail.com
}

